\title{
Shelf-life enhancement of papaya with aloe vera gel coating at ambient temperature
}

\author{
M. R. Sharmin*, M. N. Islam and M. A. Alim \\ Department of Food Technology and Rural Industries, Bangladesh Agricultural University, Mymensingh-2202, \\ Bangladesh, *Email: rasa31bd@gmail.com
}

\begin{abstract}
In this experiment the effects of aloe vera gel coating on storage behavior of papaya at room temperature $\left(29^{0} \mathrm{C}\right.$ $31^{\circ} \mathrm{C}$ ) was studied. Physico-chemical parameters such as color, physical changes, moisture, ash, acidity, vitamin C, protein, fat and total soluble solids (TSS) of papaya and aloe vera was determined at 3 days interval during the storage period. Among the physico-chemical parameters, color, physical changes, total weight loss and TSS contents increased significantly, whereas moisture content, vitamin $\mathrm{C}$ and titrable acidity decreased during storage. Control and $0.5 \%$ aloe vera treated papaya decayed from 6 days onward and completely decayed within 12 days of storage. On the other hand, $1 \%$ and $1.5 \%$ aloe vera gel coated papaya maintained their shelf-life for 9 and 12 days, respectively. Some of $1.5 \%$ aloe vera coated papaya decayed after 15 days. Papaya treated with $1.5 \%$ aloe vera solution, maintained their color \& physical changes compared to other treatments up to 12 days of storage. The overall results showed the superiority of $1.5 \%$ aloe vera gel coating in extending the shelf-life of papaya upto 15 days compared to that of $0.5 \%, 1 \%$ aloe vera gel coating and control papaya. The present study describes the preparation and potential application of aloe vera gel coatings for enhancing the postharvest life and quality of papaya.
\end{abstract}

Keywords: Papaya, Aloe vera gel, Shelf-life

\section{Introduction}

Papaya (Carica papaya L.) belongs to the family of Caricaceae. Papaya is not a tree but an herbaceous succulent plant that possess self-supporting stems (Gross, 2003). It is a nutritious table fruit of high digestive value and rich in vitamins and minerals. Papaya fruits are rich in enzymes called papain and chymopapain (Oloyede, 2005). Due to poor keeping quality of papaya and difficulties of long distance transportation and preservation facilities, a large amount of this vegetable wasted and spoiled. Reports claim that about $30-50 \%$ of the harvested papaya never reach the consumers mainly because of postharvest spoilage (Mondal and Bose, 2007). Aloe vera (Aloe barbadensis Miller) is a perennial plant of liliacea family with turgid green leaves joined at the stem in a rosette pattern. Aloe vera commonly known as Gheegwar/Ghritkumari (Ramachandra and Roy, 2008). Recently, interest has increased in using aloe vera gel-based edible coating material for fruits and vegetables. This gel is tasteless, colorless and odorless. This natural product is a safe and environmentally friendly alternative to synthetic preservatives such as sulfur dioxide (Serrano et al., 2006). Aloe vera gel has been proven one of the best edible and biologically safe preservative coatings for different types of foods because of its film-forming properties, antimicrobial actions, biodegradability and biochemical properties. It is composed mainly of polysaccharides and acts as a natural barrier to moisture and oxygen, which are the main agents of deterioration of fruits and vegetables (Misir et al., 2014). Aloe vera gel coatings have a various favorable effect on fruits such as imparting a glossy appearance and better color, retarding weight loss, or prolonging storage/shelf-life by preventing microbial spoilage (Dang et al., 2008). The main purpose of this study was to assess the effect of aloe vera gel coating in extending the shelf-life of papaya including physico-chemical changes under different storage conditions.

\section{Materials and Methods}

\section{Experimental materials}

Papaya variety Shahi (BARI Papaya-1) was selected as experimental material for experiment. This is a dioeciously variety and the plant bears fruit low on the trunk. The stem color is greenish and the color of the leaves is bottle green with a light green petiole. The fruit shape is round to ovate, large size, flattened base, not so prominent apex smooth and glabrous, deep green in mature stage but greenish yellow in ripe stage, peel thick, sweet, medium juicy crispy pleasant aroma fibreless light orange pulp at pre-ripe 
stage but deep orange red in ripe, more number of seeds, seed size medium and average fruit weight 2 $\mathrm{kg}$. Papaya fruits were collected from farmer's field at Noapara under Chorkoirala village in Kotoali thana in Mymensingh district. Aloe vera leaves were collected from Mymensingh town (Notun Bazar Market).

\section{Experimental treatments and design}

The experiment comprised of four treatments viz., control, aloe vera gel $0.5 \%$ solution, aloe vera gel $1 \%$ solution, aloe vera gel $1.5 \%$ solution. The single factor experiment (post-harvest treatments) was laid out in a completely randomized design (CRD) with three replications where physicochemical properties were analyzed at 3 days intervals during the storage period.

\section{Preparation of aloe vera coating solution}

After separating aloe vera gel from the outer cortex, this colorless hydroparenchyma was blended. This mixture was then filtered to remove fibres. The liquid obtained constituted fresh aloe vera gel. Then $0.5 \%$, $1 \%, 1.5 \%$ aloe vera gel solution was prepared by dissolving $40 \mathrm{~g}, 80 \mathrm{~g}, 120 \mathrm{~g}$ aloe vera gel in 8 litres water (Enab, 2012).

\section{Application of experimental treatments}

The papaya was selected according to size, shape and color. After dipping into $0.5 \%, 1 \%$ and $1.5 \%$ aloe vera gel solution for 5 mins, the papayas were air dried and kept on trays placed on laboratory floor at room temperature. Temperature of the storage room was recorded daily during the study period with the help of a digital thermometer. The minimum and maximum temperatures during the study period of the storage room were $29^{\circ} \mathrm{C}$ to $31^{\circ} \mathrm{C}$, respectively.

\section{Color and physical changes}

External fruit characters such as color, physical changes were recorded just after harvesting the fruits, changes in skin color were recorded during storage by matching the colors with a standard color chart (Royal Horticultural Society color chart).

\section{Weight loss}

Weight losses of fruits as influenced by different post-harvest treatments were estimated using the following formula: \% Weight loss $(W L)=\frac{I W-F W}{I W} \times 100$

Where, $\mathrm{WL}=$ Weight loss (\%), IW = Initial weight of fruits $(\mathrm{g}), \mathrm{FW}=$ Final weight of fruits $(\mathrm{g})$.

\section{Moisture, Ash, Fat and Vitamin C content}

Moisture, total ash, fat, vitamin $\mathrm{C}$ content were determined by adopting the method given by Ranganna (2004).

\section{Dry matter content}

Percent dry matter content of the papaya pulp was estimated from the data obtained during moisture estimation using the following formula: \% Dry matter content $=(100$ - Percent moisture content $)$.

\section{Protein and titrable acidity}

Protein and titrable acidity was determined by using AOAC (2005) method.

\section{Total soluble solid (TSS) and $\mathbf{p}^{\mathrm{H}}$}

Total soluble solid (TSS) was determined by using an Abbe Refractometer (Model no. 8987 PujiKuki Ltd. Tokyo, Japan). The $\mathrm{p}^{\mathrm{H}}$ of the sample was measured by using PERKINFLMER Metrion-V $\mathrm{p}^{\mathrm{H}}$ meter at an ambient temperature. 


\section{Statistical analysis}

The collected data on various parameters were statistically analyzed using MSTAT statistical package. The significance of difference between the pairs of means was compared by least significant difference (LSD) test at the $1 \%$ levels of probability (Gomez and Gomez, 1984).

\section{Results and Discussion}

The control fruits started deteriorated before 6 days and only few fruits survived upto 7 days, whereas, shelf life extended to 15 days for majority of $1.5 \%$ aloe vera gel coated fruits. Therefore, data for $1 \%$ and $0.5 \%$ aloe vera gel coated fruits was given only till 12 and 9 days, respectively. This could be attributed to the delayed ripening process. In climacteric fruits like papaya, an increase in ethylene production during ripening is a normal physiological process. Reduction of ethylene production was higher in $1.5 \%$ aloe vera gel coated papaya than $1 \%, 0.5 \%$ aloe vera gel coated papaya and control papaya, respectively.

\section{Composition of papaya pulp and aloe vera gel}

Variation in composition of papaya at different days after storage was effected by different aloe vera gel coating. On first day, the papaya pulp contained $93.042 \%$ moisture, $0.25 \%$ ash, $0.8 \%$ protein, $0.1 \%$ fat, $42.312 \mathrm{mg} / 100 \mathrm{~g}$ vitamin $\mathrm{C}, \mathrm{p}^{\mathrm{H}} 4.8,0.256 \%$ acidity, TSS $4^{0}$ Brix, respectively. According to Nwofia et al. (2012), papaya pulp contain $89.4 \%$ moisture, $0.31 \%$ ash, $0.37 \%$ fat, $0.9 \%$ protein, respectively. Zaman et al. (2006) found that the moisture, total solid protein, $\mathrm{p}^{\mathrm{H}}$ and vitamin $\mathrm{C}$ content of green papaya of Deshi variety were $88 \%, 12 \%, 4.3$ and $41 \mathrm{mg} / 100 \mathrm{~g}$, respectively. On the other hands, in fresh aloe vera gel $96.87 \%$ moisture content, $0.165 \%$ ash, $0.061 \%$ protein, $0.021 \%$ fat, respectively were found. Ahmed and Hussain (2013) revealed that moisture content of aloe vera were $97.42 \pm 0.13 \%$, while ash, fiber, protein and fat contents were $16.88 \pm 0.04 \%, 73.35 \pm 0.30 \%, 6.86 \pm 0.06 \%$ and $2.91 \pm 0.09 \%$, respectively along with traces of ascorbic acid $(0.004 \pm 0.05 \%)$. The differences observed in these compositions may be due to varietal differences, seasonal and reasonal effects, agro-ecological condition, fertilizer use, methods of analysis etc. Variation in composition in different days has been shown in Table 1 and Table 2.

\section{Physical change pattern of papaya during storage}

Color and physical change pattern of papaya during storage: During the storage period, the color of papaya changed from green to greenish yellow. The results revealed that the changes in color and physical change pattern of control and $0.5 \%$ aloe vera treated papaya showed within 5 days where $1 \%$ and $1.5 \%$ aloe vera treated papayas retarded color and physiological changes upto 9 and 12 days, respectively. Color retention of coated papaya was due to delay in ripening of coated papaya. Aloe vera gel coating material retarded the ethylene production rate, therefore, delaying ripening, chlorophyll degradation, anthocyanin accumulation and carotenoid synthesis thus ultimately delaying color change of papayas (Carrillo-Lopez et al., 2000).

Weight loss: Weight loss gradually increased in control papaya compared to other treated papaya. Control papaya showed the highest weight loss (16.90\%) and the lowest was in papaya preserved with $1.5 \%$ aloe vera gel solution $(7.30 \%)$. In case of $1 \%$ and $0.5 \%$ aloe vera gel coated papaya weight loss were $9.39 \%$ and $10.81 \%$, respectively (Table 1). Brishti et al. (2013), examined that in aloe vera coated papaya, no disease signs were observed until 1 week after the beginning of the storage period. The weight loss in papaya during storage may be attributed to substrate loss by respiration and to loss of water through various mechanisms. This treatment was effective as a physical barrier and thus reduced the weight loss during post-harvest storage.

\section{Chemical composition change of papaya}

Moisture content: The results indicate that the moisture content was gradually decreased during the storage period. The moisture content was lower in control papaya compared to $0.5 \%, 1 \%$, and $1.5 \%$ aloe vera treatment (Table 1). The decrease in moisture content during storage was reported by Pathmanaban et al. (1995). The decrease of moisture content was probably due to transpiration and evaporation loss and also due to starch hydrolysis. 
Table 1. Effects of aloe vera coating on weight loss and moisture content of papaya

\begin{tabular}{|l|c|c|c|c|c|c|c|c|}
\hline \multirow{2}{*}{ Concentration } & \multicolumn{4}{|c|}{ Weight loss (\%) } & \multicolumn{4}{c|}{ Moisture content \% } \\
\cline { 2 - 10 } & 3 DAS $^{\star}$ & 6 DAS & 9 DAS & 12 DAS & 3 DAS & 6 DAS & 9 DAS & 12 DAS \\
\hline Control & $9.910^{\mathrm{a}}$ & $12.27^{\mathrm{a}}$ & $13.65^{\mathrm{a}}$ & $16.90^{\mathrm{a}}$ & $89.74^{\mathrm{b}}$ & $85.61^{\mathrm{b}}$ & $86.50^{\mathrm{c}}$ & $85.36^{\mathrm{a}}$ \\
\hline $0.5 \%$ aloe vera gel solution & $6.900^{\mathrm{b}}$ & $8.040^{\mathrm{b}}$ & $9.730^{\mathrm{b}}$ & $10.81^{\mathrm{b}}$ & $91.59^{\mathrm{a}}$ & $89.82^{\mathrm{a}}$ & $87.87^{\mathrm{bc}}$ & $86.64^{\mathrm{c}}$ \\
\hline $1 \%$ aloe vera gel solution & $6.330^{\mathrm{b}}$ & $7.710^{\mathrm{b}}$ & $8.410^{\mathrm{c}}$ & $9.390^{\mathrm{c}}$ & $91.81^{\mathrm{a}}$ & $90.09^{\mathrm{a}}$ & $88.41^{\mathrm{b}}$ & $87.83^{\mathrm{b}}$ \\
\hline $1.5 \%$ aloe vera gel solution & $5.090^{\mathrm{c}}$ & $5.730^{\mathrm{c}}$ & $6.350^{\mathrm{d}}$ & $7.300^{\mathrm{d}}$ & $92.77^{\mathrm{a}}$ & $91.77^{\mathrm{a}}$ & $90.37^{\mathrm{a}}$ & $89.40^{\mathrm{a}}$ \\
\hline LSD & $1.24^{\star \star}$ & $1.59^{\star \star}$ & $1.24^{\star \star}$ & $1.35^{\star \star}$ & $2.12^{\star \star}$ & $3.83^{\star \star}$ & $2.31^{\star \star}$ & $0.561^{\star \star}$ \\
\hline CV (\%) & 6.45 & 6.90 & 4.78 & 4.44 & 0.85 & 2.74 & 0.96 & 0.24 \\
\hline
\end{tabular}

*Days after storage; ** Significant at $1 \%$ level of probability followed by different Duncan's Multiple Range Test (DMRT) letters

\section{Dry matter content}

The scientific information regarding percent dry matter content of papaya is not available during storage. Control papaya showed the highest dry matter contents compared to $0.5 \%, 1 \%, 1.5 \%$ aloe vera treated papayas (Fig. 1). However, Selvaraj et al. (1982) studied with papaya cv. Thailand and observed that dry matter was increased considerably from the earliest stage of development until 140 days after an experiment. The increase in dry matter percent with increasing storage period may be due to osmotic withdrawal of water from the pulp.

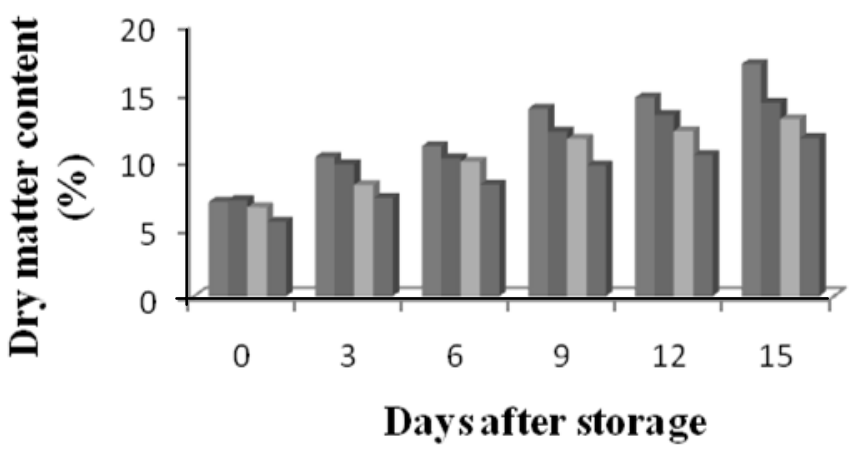

control

- $0.5 \%$ aloevera gel solution

$1 \%$ aloe vera gel solution

$1.5 \%$ aloevera gel solution

Fig. 1. Main effects of post-harvest treatments of aloe vera gel solution on dry matter content of papaya at different days after storage

\section{Total soluble solids}

Total soluble solids contents of papaya pulp of different treatments increased gradually. The highest total soluble solids content (11.47\%) was found at 12 day of storage in control papaya and the lowest total soluble solids content $(7.610 \%)$ was found in papaya preserved with $1.5 \%$ aloe vera gel solution (Table 2 ). The increase in TSS of control papaya was mainly due to the progressive boost in free sugars of papaya during storage periods, as reported by Cheour et al. (1990). Coated papaya retarded TSS development because aloe gel decreases the respiration and eventually matabolism of sugars. This may be due to the effect of aloe vera gel coating on the reduction of $\alpha$-galactosidase, polygalacturonase and pectinmethylesterase activities (Nunan et al. 1998).

\section{Titrable acidity}

Due to the effect of different post-harvest treatments of aloe vera gel solution during storage period titrable acidity did not vary significantly. However, it was found that the papaya treated with $1.5 \%$ aloe vera gel solution gave the maximum $(0.41 \%)$ titrable acidity at 12 days of storage whereas the minimum $(0.39 \%)$ titrable acidity was found in $0.5 \%$ aloe vera treated papaya (Table 2$)$. This retention of TA content by coated papaya was due to the protective effect of aloe gel coating as a barrier to $\mathrm{O}_{2}$ from the surrounding atmosphere (Valverde et al., 2005) and reduction of respiration (Srinu et al. 2012). 
Table 2. Effects of aloe vera coating on TSS and acidity of papaya

\begin{tabular}{|l|c|c|c|c|c|c|c|c|}
\hline \multirow{2}{*}{ Concentration } & \multicolumn{4}{|c|}{ TSS (\%) } & \multicolumn{4}{c|}{ Acidity } \\
\cline { 2 - 10 } & 3 DAS $^{\star}$ & 6 DAS & 9 DAS & 12 DAS & 3 DAS & 6 DAS & 9 DAS & 12 DAS \\
\hline Control & $8.690^{\mathrm{a}}$ & $10.00^{\mathrm{a}}$ & $10.90^{\mathrm{a}}$ & $11.47^{\mathrm{a}}$ & $0.33^{\mathrm{a}}$ & $0.37^{\mathrm{a}}$ & $0.39^{\mathrm{a}}$ & $0.40^{\mathrm{a}}$ \\
\hline $0.5 \%$ aloe vera gel solution & $8.160^{\mathrm{b}}$ & $8.160^{\mathrm{b}}$ & $9.250^{\mathrm{b}}$ & $10.16^{\mathrm{a}}$ & $0.33^{\mathrm{a}}$ & $0.36^{\mathrm{a}}$ & $0.37^{\mathrm{a}}$ & $0.39^{\mathrm{a}}$ \\
\hline $1 \%$ aloe vera gel solution & $6.970^{\mathrm{c}}$ & $7.610^{\mathrm{bc}}$ & $8.080^{\mathrm{C}}$ & $8.410^{\mathrm{b}}$ & $0.32^{\mathrm{a}}$ & $0.37^{\mathrm{a}}$ & $0.39^{\mathrm{a}}$ & $0.40^{\mathrm{a}}$ \\
\hline $1.5 \%$ aloe vera gel solution & $4.650^{\mathrm{d}}$ & $6.660^{\mathrm{c}}$ & $7.140^{\mathrm{d}}$ & $7.610^{\mathrm{b}}$ & $0.35^{\mathrm{a}}$ & $0.38^{\mathrm{a}}$ & $0.39^{\mathrm{a}}$ & $0.41^{\mathrm{a}}$ \\
\hline LSD & $0.554^{\star *}$ & $1.83^{\star *}$ & $1.30^{\star \star}$ & $2.10^{\star \star}$ & $0.049^{\mathrm{NS}}$ & $0.049^{\text {NS }}$ & $0.043^{\text {NS }}$ & $0.050^{\text {NS }}$ \\
\hline CV $(\%)$ & 2.83 & 8.26 & 5.36 & 8.15 & 5.42 & 4.87 & 4.11 & 4.51 \\
\hline
\end{tabular}

*Days after storage; ** Significant at $1 \%$ level of probability and ${ }^{N S}$ means Non significant probability followed by different Duncan's Multiple Range Test (DMRT) letters

\section{Vitamin C (Ascorbic acid) content}

Ascorbic acid content was higher in $1.5 \%$ aloe vera treated papayas and lower was in control papayas. On first day vitamin C content were $42.71,43.25,42.50,42.312 \mathrm{mg} / 100 \mathrm{~g}$ in $1.5 \%, 1 \% \quad 0.5 \%$ aloe vera gel coated and control papayas, respectively and 37.658, 36.654, 34.932, $30.504 \mathrm{mg} / 100 \mathrm{~g}$ in $1.5 \%, 1 \%$, $0.5 \%$ aloe vera gel coated and control papayas at 12 day of storage (Figure 2). The coated papayas were exposed to more light intensity during growth for which they contained higher AA than the control papaya. Singh et al. (1999) reported that the decreased in vitamin C content with storage duration is attributed to the oxidation of ascorbic acid into dehydro ascorbic acid by enzyme ascorbic acid oxidase. Aloe vera gel coatings were effective in reducing the ascorbic acid loss in storage conditions.

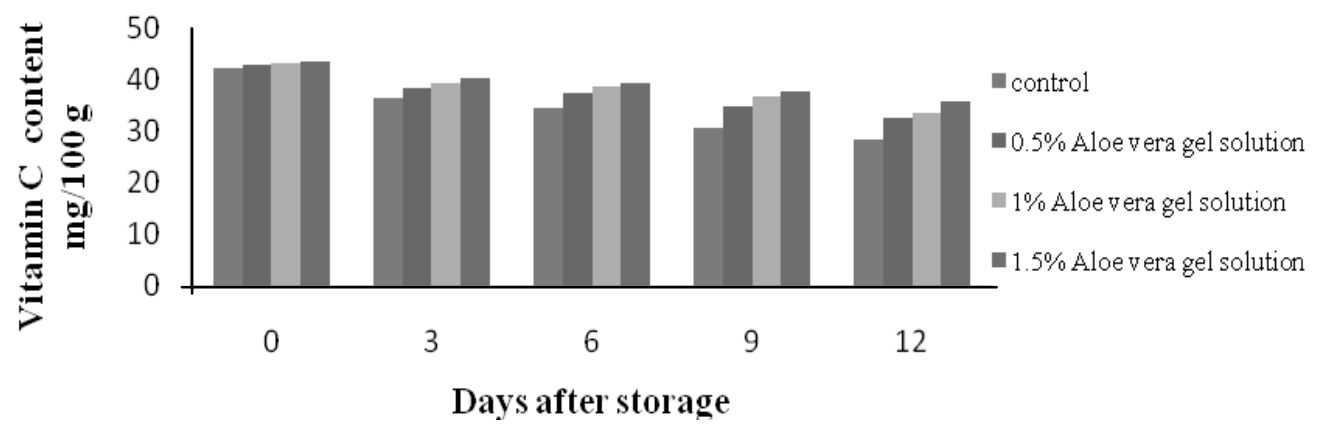

Fig. 2. Main effect of post-harvest treatments of aloe vera gel solution on vitamin C content of papaya at different days after storage

\section{Shelf-life}

The post-harvest treatments used in the present study exhibited pronounced effect on extending shelf-life of papaya during storage and it was statistically significant.

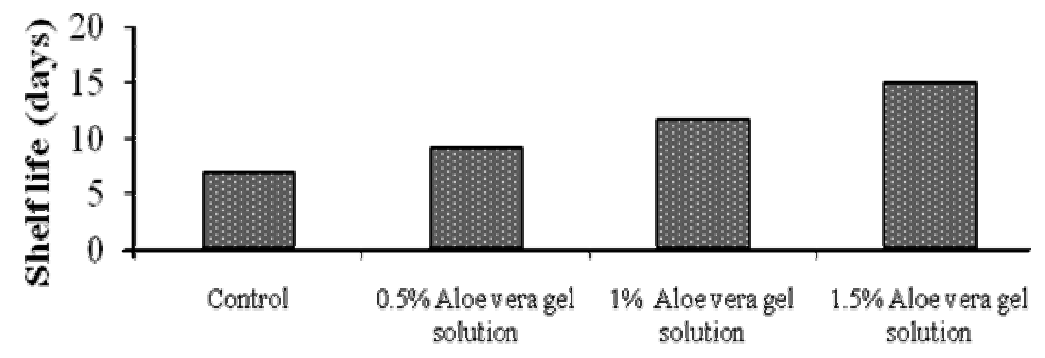

\section{Concentration}

Fig. 3. Main effects of post-harvest treatments of aloe vera gel solution on shelf-life of papaya at different days after storage 
The longest shelf-life (15 days) was found in papayas preserved with $1.5 \%$ aloe vera gel solution, whereas minimum shelf-life (6.870 days) was found in control papaya. Preceded by that shelf-life of papaya in $0.5 \%$ and $1 \%$ aloe vera gel solution were 9 and 11.67 days, respectively (Figure 3 ). Shelf-life of any fruits calculated from the period of harvest up to rotting. Similar experiment was also done by Mondal (2000) who showed that the shelf-life was the period of time which started from the time of harvesting and extended up to the start of rotting of fruit and it is the basic quality of fruit as well as it is the most important parameter in loss of reduction biochemical reaction of fruit.

\section{Conclusion}

This work recommends aloe vera gel coating as a successful bio-preservative and a useful alternative to synthetic preservative. To effectively extend the shelf life of postharvest fruits and vegetables, aloe vera gel-based coating as a relatively convenient and safe measure, is more and more concerned in food industry in recent years. Another advantage of this coating is totally harmless to the environment. In fact it can be considered as a green alternative to synthetic coatings and other postharvest chemical treatments. Chemical preservatives which are now used widely can have dangerous effects on health such as various types of cancers, kidney and liver damage, etc. Considering the above stated findings, further studies are suggested to carry out for examining the effects of other promising non-chemical plant pesticides with series of concentrations on shelf-life and quality of papaya fruits as well as other fruits grown in Bangladesh.

\section{References}

Ahmed, M. and Hussain, F. 2013. Chemical composition and biochemical activity of aloe vera (Aloe barbadensis Miller) leaves. Int. J. Chem. Biochem. Sci., 3: 29-33.

AOAC 2005. Official methods of analysis. Association of official analytical chemists. $18^{\text {th }}$ edition, Washington D. C.

Brishti, F.H., Misir, J. and Sarker, A. 2013. Effect of biopreservatives on storage life of papaya fruit (Carica Papaya L.). Int. J. Food Studies, 2(1): 126-136.

Carrillo-Lopez, A., Ramirez-Bustamante, F., Valdez-Torres, J., Rojas-Villegas, R. and Yahia, E. 2000. Ripening and quality changes in mango fruit by coating with an edible film. J. Food Quality, 23(5): 479-486.

Cheour, F., Willemot, C., Arul, Y., Desjardins, J., Makhlouf, P. and Gosselin, A. 1990. Effects of foliar application of Cacl 2 on postharvest strawberry ripening. J. Am. Soci. Hort. Sci., 115(5): 789-792.

Dang, K.T., Singh, Z. and Swinny, E.E. 2008. Edible coatings influence fruit ripening, quality and aroma biosynthesis in mango fruit. J. Ani. Plant Sci., 56: 1361-1370.

Enab, R.N. 2012. Effects of edible non-edible coating materials on shelf-life of banana. MS Thesis, Deptartment of Horticulture, BAU, Mymensingh.

Gomez, K.A. and Gomez, A.A. 1984. Statistical procedures for agricultural research. J. Willey and Sons, New York. pp. 28-92.

Gross, D. 2003. Papaya: A tantalizing tastes of the tropics. Master Gard. J., 6: 12-14.

Misir, J., Brishti, H.F. and Hoque, M.M. 2014. Aloe vera gel as a novel edible coating for fresh fruits: a review. American J. Food Sci. Tech., 2(3): 93-97.

Mondal, M.F. 2000. Production and storage of fruits (in Bangla). BAU Campus, Mymensingh-2202.

Nunan, K.J., Sims, I.M., Bacic, A., Robinson, S.P. and Fincher, G.B. 1998. Changes in cell wall composition during ripening of grape berries. Plant Physio., 118(3): 783-792.

Nwofia, G.E., Ojimelukwe, P. and Eji, C.J.A. 2012. Chemical composition of leaves, fruits pulp and seeds in some Carica papaya (L). Int. J. Medi..Aro. Plants, 2(1): 200-206.

Oloyede, O. 2005. Chemical profile of unripe pulp of carica papaya. Pakistan J. Nutr., 4(6): 379-381.

Pathmanaban, G., Nagarajan, M., Manian, K. and Annamalainathan, K. 1995. Effect of using calcium salts on post-harvest preservation in fruits. Madr. Agri. J., 82: 47-50.

Ramachandra, C.T. and Rao, P.S. 2008. Processing of aloe vera leaf gel: a review. Am. J. Agri. Biol. Sci., 3(2): 502-510.

Ranganna, S. 2004. Hand book of analysis of fruits and vegetable products. Tata McGrow Hill Cl. Ltd., New Delhi, India. pp. 1-30.

Selvaraj, Pal, Y.D.K., Subramanyan, M.D. and Lyer, C.P.A. 1982. Changes in the chemical composition of four cultivers of papaya (Carica papaya L.) during growth and development. J. Hort. Sci., 57: 135-143.

Serrano, M., Valverde, J., Guillen, F., Castillo, S.,Martinez-Romero, D. and Valero, D. 2006. Use of Aloe vera gel coating preserves the functional properties of table Grapes. J. Agri. Food Chem., 54(11): 3882-3886.

Singh, H., Korpraditskul, V. and Singh, P.P. 1999. Evaluation of some plant extracts for the control of Collitotrichum capsici (SYD). Butler and Bishy, the causal agent of chilli anthracnose. Azadirachta indica Juss., 12: 131-138.

Srinu, B., Vikram, K.B., Rao, L.V., Kalakumar, B., Rao, T.M. and Reddy, A.G. 2012. Screening of antimicrobial activity of Withania somnifera and Aloe vera plant extracts against food borne pathogens. J. Chem. Pharma. Research, 4(11): 4800-4803.

Valverde, J., Valero, D., Martinez-Romero, D., Guillen, F., Castillo, S. and Serrano, M. 2005. Novel edible coating based on aloe vera gel to maintain table grape quality and safety. J. Agri. Food Chem., 53(20): 7807-7813.

Zaman, W., Biswas, S.K., Helal, M., Ibrahim, M. and Hassan, P.J.A. 2006. Physico-chemical composition of four papaya varieties grown at Rajshahi. Biol. Sci., 14: 83-86. 